\title{
DEVELOPING COMPUTER-ASSISTED HOTEL FRONT OFFICE ENGLISH LISTENING MATERIALS FOR STUDENTS OF TOURISM SCHOOL IN BALI
}

\author{
K.T. ASTINI ${ }^{1}$, I.N.A.J. Putra ${ }^{2}$, M. H. SANTOSA ${ }^{3}$ \\ ${ }^{123}$ English Language Education, Post Graduate Program, Universitas Pendidikan Ganesha, Singaraja \\ e-mail: astinniie@gmail.com, jaya.putra@pasca.undiksha.ac.id, hery.santosa@pasca.undiksha.ac.id
}

This study aimed at exploring materials that should be developed in computer-assisted hotel front office English listening materials for students of tourism school, explaining ways to develop computer-assisted hotel front office English listening materials for students of tourism school in Bali, and analyzing the quality of computer-assisted hotel front office English listening materials for student of tourism school in Bali. This study applied ADDIE model Research and Development design. The steps were analyzing, designing, developing, implementing, and evaluating. From the need analysis, it was found that listening activity was one of the skills that got the least attention. Therefore, developing listening material in the context of front office was an urgent need. In the development, several data were collected through observation, interview, and document analysis. There were five topics developed based on the collected data, they were Hotel Check-in, Hotel Check-in with No Reservation, Giving Recommendation, Hotel Check-out, and Hotel Check-out with Problem. The resource materials followed good material criteria proposed by Tomlinson (1998) and good listening text criteria by Wilson (2008). Using the quality measurement, the developed resource material was 169.3 (good).

Key words: English for hotel front office, Computer-Assisted listening materials.

\section{INTRODUCTION}

ASEAN Economic Community (AEC) is a new project which has been implemented since the end of 2015 as the realization of the end goal of economic integration (ASEAN, 2008). AEC envisage four key characteristics, one of them is a single market and production base. An ASEAN single market and production base shall comprise five core elements, they are (i) free flow of goods, (ii) free flow of services, (iii) free flow of investment, (iv) freer flow of capital, and (v) free flow of skilled labors. The fifth core element will facilitate the issuance of visas and employment passes for ASEAN professionals and skilled labor who are engaged in cross-border trade and investment facilities. Furthermore, it will also facilitate the free flow of service which will automatically open a huge opportunity for skilled labor to work in other ASEAN countries.

The Tourism has been one of the key growth sectors in ASEAN and has proven strong among economic challenges globally. The wide range of tourist destinations across the region has attracted 81 million tourists to ASEAN in 2011 which significantly improved since 2007. The sector has seen increased interest not only from usual markets in Europe and the Americas but also from Asia's economic giants and emerging markets. Based on DBS Asian Insights (2016) travel and tourism accounted for 12.4\% of ASEAN's GDP in 2015, according to the World Travel \& Tourism Council (WTTC), compared with an average of $8.5 \%$ in Asia Pacific and $9.8 \%$ globally. The ASEAN Tourism Strategic Plan (ATSP) targets tourism to make up $15 \%$ of ASEAN GDP by 2025.

Hotels are important globally as providing the facilities for recreation and entertainment, meeting and conferences and business transmission. Bardi (2003) argued that a hotel usually offers guests a full range of accommodations and services, which may include reservations, suites, public dining and banquet facilities, lounge and entertainment areas, room service which can range from 20 to more than 2,000 rooms.

The front office is the nerve center of a hotel property (Bardi, 2003). Communication and accounting are two of the most important functions of a front desk operation. Effective 
communication with guests, employees, and other departments of the hotel are paramount in projecting a hospitable image. Answering guest inquiries about hotel services and other guests, marketing and sales department requests for information on guest room availability, and housekeeping department inquiries concerning guest reservations are but a few of the routine tasks performed almost constantly by a hotel front desk in its role as communications hub.

Based on the preliminary interview with practitioner, it was found that English is important for hotel front office staff in managing a successful communication especially to the guest as it is accepted as the language of global communication. Therefore, it is urgent to give suitable English training for the training participant to be a skilled labor that can compete in ASEAN Economy community.

The training participants should focus in improving their ability to use the language in real communication as a practical English skill as well as the mastery of knowledge-based grammar and vocabulary which are not an easy task. They need to use English in the context of performing. Therefore, Yamada, Kitamura, Shimada, Utashiro, Shigeta, Yamaguchi, Harrison, Yamauchi, Nakahara (2011) assert that the learning materials should be designed to enable learners to successfully reach it.

As they are going to perform in tourism area, ESP will suit them as they should master certain terms needed to address the guests' needs appropriately.ESP stands for English for Specific Purposes (Richard \& Schmidt, 2002). ESP is related to specific terminologies and specific communication used for specific needs (Hutchinson and Waters, 1998). Further, Bierema and Merriam (2014) states ESP is good for adult learners who have worked in the specific field because adult learners have different need and reason for learning to deal with an issue or problem of immediate concern. Celce-Murcia (2001) also adds to develop the quality, an ESP practitioner needs to have or develop appropriate material. All the material should be in chains to the specific learning and language use needs of identifying groups of student and also sensitive to socio-cultural context in which these students will use English.

Achieving high English proficiency is challenging for Indonesian training participants. A suitable learning material has an important role to accommodate the training participants to achieve the target as it helps trainers to conduct an effective training process. Learning materials are defined as anything that can be used to facilitate them learning of a language, including course books, videos, graded readers, flash cards, games, websites and mobile phone interactions, though, inevitably, much of the literature focuses on printed materials (Tomlinson, 2012). Materials are the vital component concerning what happens inside the ESP classroom because they control the process of teaching and learning. Watkins (2014) supports by stating that material is one of the things that impacts on the learning and teaching process. Further, he also asserts that materials should support learning. Therefore, it has to be selected by addressing the learners' needs and exploited in a way that engages the learners' interest and encourages them to process and experiment with new language items.

Ideally, the materials should cover balance proportion of reading, listening, speaking and writing activities. Unfortunately, based on the preliminary interview and observation in one of prestigious institution in Bali, torism school in Bali, listening activities seemed to be ignored.

The tourism school in Bali used an excellent curriculum which is Common ASEAN Tourism Curriculum (CATC). Textbook is provided to support the English training process. The textbook indeed covers reading, writing, listening, and speaking activities but, the portion of listening text covered in the textbook were very small compared to the other skills. Moreover, the materials that covered in the listening activities include more General English rather than ESP. This urgency motivated the researcher to develop front office English listening resource materials for Hotel Accommodation Division students of Tourism school in Bali. The materials were expected to improve participants English communication skills so that Mediterranean has competent graduates that qualified and meet the standard of skilled labor to compete especially in ASEAN. 
There were three research questions which were investigated in this study: (1) What materials need to be developed for students of hotel accommodation division of Mediterranean Hotel and Cruise Line Training Centre? (2) How should the materials for students of hotel accommodation division of Mediterranean Hotel and Cruise Line Training Centre be developed? (3) How is the quality of the developed materials for students of hotel accommodation division of Mediterranean Hotel and Cruise Line Training Centre?

Based on the research questions, the objectives of this study were: (1) to explore materials that should be developed for student of Hotel Accommodation division of Tourism school in Bali; (2) to explain steps in developing materials student of Hotel Accommodation division of Tourism school in Bali; (3) to analyze the quality of materials developed student of Hotel Accommodation division of Tourism school in Bali as perceived by the experts, and a practitioner.

This study applied ADDIE model R\&D design by McGriff (2000). ADDIE stands for Analysis, Design, Development, Implementation and Evaluation. Each of the components is crucial as they are related each other. Analyzing is the process of defining the subject of the study, skills, knowledge and kinds of materials that needed by this subject. In this stage, current teaching and learning process of the subject is also important to be analyzed. This step is really important in order to set up the goal of the project and determining the scope of it. Designing is the process of specifying the way to develop a product that can improve current situation of the teaching and learning process. Developing is the process of creating the learning materials. Implementing is the process of delivering the project to the subject of the study. Evaluating is the process of determining the effectiveness and efficiency of the instruction.

The resource materials were developed in MoodleCLoud-https://receptionistenglish.moodlecloud.com/. It is an online learning platform which will enable the learners to experience a new learning strategy as it can be accessed from their PC or their mobile phone. It consists of interactive vocabulary and comprehension quiz to check students' understanding. Technology in language teaching is not new. Indeed, technology has been around in language teaching for decades (Dudeney and Hocky, 2007). The advantages of ICT usage in Foreign Language Teaching are capacity to control presentation, novelty and creativity, fast feedback, and adaptability that enables the teacher to make changes whenever needed.

Having theory to control the quality of the product of this study is really important. The resource materials were developed according to Tomlinson (2003), a good material should follow these criteria; (1) Materials should achieve impact. (2) Materials should help learners to feel at ease. (3) Materials should help learners to develop confidence. (4) What is being taught should be perceived by learners as relevant and useful. (5) Materials should require and facilitate learner self-investment. (6) Learners must be ready to acquire the points that are taught in the classroom. (7) Materials should expose the learners to language in authentic use. (8) Learners attention should be drawn to linguistics features of the input. (9) Materials should provide the learners with opportunities to use the target language to achieve communicative purposes. (10) Materials should take into account that positive effects of instruction are usually delayed. (11) Materials should take into account that learners differ in learning styles. (12) Materials should take into account that learners differ in affective attitudes. (13) Materials should permit a silent period at the beginning of the instruction. (14) Materials should maximize learning potential by encouraging intellectual, aesthetic and emotional involvement which stimulates both left and right brain activities. (15) Materials should not rely too much on controlled practice. (16) Materials should provide opportunities for outcome feedback.

Moreover, Wilson (2008) mentioned factors of a good listening text which grouped into content and delivery factor were used in the developing of this listening resource materials. Part of content's factor are interest factors, entertainment factors, cultural accessibility, speech acts, discourse structures, density, and language level. Delivery factors involve mode, length, quality and accent. Thus, the English listening materials had a good quality 
which is in line with the development of the technology were expected to be effective to improve students' communication skills.

\section{RESEARCH METHOD}

This study was designed based on ADDIE model by McGriff (2000). The steps of study procedure are described as follow:

1. Analyzing

2. Designing

3. Developing

4. Implementing

5. Evaluating

In this study the researcher analyze the situation need through observation and interview. Observation checklist and interview guideline were used to limit the focus of the process. Both the observation checklist and the interview guideline were developed based on need analysis theory proposed by Hutchinson and Waters (1987). The observation focused on the English training activity, the available resource, the students, the place and existing facility where the training is conducted and the duration of the training. In the interview, the researcher interviewed the English instructors, students of Hotel Accommodation Division and practitioners that experienced in working as front office staff in the prestigious hotels. The interview focused on finding the importance of English, English skills and English materials that needed to be a competent front office staff.

In the process of designing the material, this study apply the presentation of material development suggested by Hutchinson and Waters (1987) which include (i) input, (ii) content focus, (iii) language focus, (iv) task. In this stage, the researcher did a document analysis. The researcher analyzed curriculum, syllabus, and action plan that were used by the English instructors. Moreover, in this stage the researcher also find published books or materials that provide similar topics that needed by the students when learning front office English. This was done in order to get suitable expressions to be included in the recordings.

In designing process, the researcher finished writing the script to be recorded and tasks that supported the learning. The recording was done in a music studio to guarantee the quality of the recordings. There were two competent English lecturers from prestigious university and language foundation involved in the process of the recordings. After the recordings finished, the researcher then create a free MoodleCloud account where the materials were developed. The researcher then started to create activities that support the learning of English which focused on improving listening skills of the students in MoodleCloud. The materials then could be access online from PC or mobile phone.

In implementation, the materials were tried by experts and a practitioner. The researcher created username and password for the experts and the practitioner so that they can access the materials.

In getting the proper material, the developed materials were revised based on the result of the critics from the experts of this study to achieve higher quality standard as part of evaluation process.

The material was designed as simple as possible by using Hutchinson and Water Material Design Framework (1987). In the input, the researcher created a discussion section. A picture used to stimulate student to speak and tell what they think about the picture. In the content focus, the researcher created comprehension section. It consists of questions that test the students understanding towards the recording. In the language focus, the researcher created key phrase section. In this section the students could practice their pronunciation and spelling both words and also phrases that related to the recording. In the task, the researcher created practice section. The students could do many quizzes related to the topic. Moreover, the students also should do speaking task which assigns the students to produce conversation based on the topic that they learnt.

\section{Quality of the product}


The evaluation scoring rubric format is designed based on Tomlinson (1998) theory of material criteria. It used 5 scales of scoring, in which 5 represents strongly agree, 4 is for agree, 3 is to fairly agree, 2 is for disagree, and 1 is for strongly disagree.

In determining the quality of the material designed, a formula of scoring material design by Candiasa (2010:64) was adopted. The formula is presented as follows:

\begin{tabular}{|c|c|c|}
\hline Criteria & Interval & $\begin{array}{c}\text { Validity } \\
\text { Categor }\end{array}$ \\
\hline $\begin{array}{l}\text { Mi }+1,5 \text { Sdi } \leq \max \\
\text { score }\end{array}$ & $\begin{array}{l}0,750 \leq \\
1,000\end{array}$ & $\begin{array}{l}\text { Very } \\
\text { High }\end{array}$ \\
\hline $\begin{array}{l}\mathrm{Mi}+0,5 \mathrm{Sdi} \leq \mathrm{Mi}+ \\
1,5 \mathrm{SDI}\end{array}$ & $\begin{array}{l}0,580 \leq \\
0,750\end{array}$ & High \\
\hline $\begin{array}{l}\mathrm{Mi}-0,5 \mathrm{Sdi} \leq \mathrm{Mi}+ \\
0,5 \mathrm{Sdi}\end{array}$ & $\begin{array}{l}0,420 \leq \\
0,580\end{array}$ & Average \\
\hline $\begin{array}{l}\mathrm{Mi}-1,5 \text { Sdi } \leq \mathrm{Mi}- \\
0,5 \mathrm{Sdi}\end{array}$ & $\begin{array}{l}0,260 \leq \\
0,420\end{array}$ & Low \\
\hline $\begin{array}{l}\text { Min score } \leq \mathrm{Mi}-1,5 \\
\text { Sdi }\end{array}$ & $\begin{array}{l}0,000 \leq \\
0,260\end{array}$ & Poor \\
\hline \multicolumn{3}{|c|}{$\begin{array}{l}\text { Description: } \\
\mathrm{Mi}=1 / 2 \text { (score max }+ \text { score } \min ) \\
\mathrm{Sdi}=1 / 3(\mathrm{Mi}) \\
\mathrm{Mi}=\text { Ideal mean } \\
\mathrm{Sdi}=\text { Standard of Deviation }\end{array}$} \\
\hline
\end{tabular}

Table 1: Formula of Scoring Mateial

\section{FINDING AND DISCUSSION Findings}

The result of the observation are: (1) The learners are high school graduates who are 18-20 years old. They are not only from Denpasar but also come from Java and Sulawesi. They learn English 90 - 135 minute in a day; 225 minute in a week. The teacher usually conducted English games before starting the lesson. (2) In the input session, lecturing and reading were dominating the class activity whereas listening conducted rarely. (3) In the production session, the students did role play. Students included functional language that they have learned in their conversation. (4) All students owned a textbook which developed by head of curriculum of Mediterranean Hotel and Cruise Line Training Center. This book is adapted from ASEAN Common Competency Standards for Tourism Professional. (5) Most of the English instructors had earned their master degree either from English literature faculty or English teacher training and education faculty. (6) In terms of teaching aids, the teachers mostly used PowerPoint presentation to deliver the materials. (7) Tourism school in Bali supported by complete facilities. Including library, and language laboratory that equipped with computers and high speed internet connection.

The result of the interview: (1) Most participants agreed that English considered as important for being a competent front office staff. (2) English dominates the language that will be used by the receptionist. In Bali, the guests are mostly from other countries. (3) Speaking and listening skills are two important skills for a receptionist because that is most of activity that they do. (4) Topics should cover check-in and check-out.

The result of the document analysis is Mediterranean Hotel and Cruise Line Training Center applied Common ASEAN Tourism Curriculum. The CATC is founded upon six labour divisions: Front Office, Housekeeping, Food Production, Food \& Beverage Service, Travel Agencies and Tour Operations. CATC supports and contributes to the development of a harmonized tourism education and training framework within the ASEAN region. 
CATC aims at providing an efficient and practical model for the delivery of vocational training which can be expected to prove popular with industry, students and training providers (The ASEAN Task Force on Tourism Manpower Development, 2012). The model is straightforward and consistent across all Secondary Labour Divisions of Travel Agencies, Tour Operation, Housekeeping, Front Office, Food and Beverage Service, and Food Production. It offers qualifications in each of the labour divisions from Certificate II level to Advanced Diploma level.

There were eleven unit competencies of ELT that covered in the Common ASEAN Tourism Curriculum used in Tourism school in Bali.This study was focused on one unit competency entitles "Start conversations and develop good relations with guests". The unit covers 3 elements. The first element is related to meet and greet guests. It covers welcome guest appropriately, introduce self to others and ask question to involve guests. The second element is about responding to guests' questions or requests. It involves giving answers clearly and honestly, requesting repetition or clarification of questions or requests, Offering to fulfill guest' request in a timely manner, providing explanation and apologize if unable to answer questions or fulfill requests and offering to seek help from other sources if unable to fulfill guests' requests or answer questions. The third element is about participating in a short, informal conversation with guests. It covers start a conversation using appropriate topics, demonstrate turn taking techniques to hold and relinquish turns in a conversation, show interest in what a guest is saying, and close a conversation politely.

There were some considerations why that unit competency was used to develop Integrated Computer-Based English Materials (1) The first unit that will be discussed on the second semester. (2) Based on the interview, the practitioner mentioned that it is important for the receptionist to build a good communication with the guest by making a good first impression. Therefore, being able to start a conversation and develop good relations with guest will benefit them. (3) This unit covers the situations that a hotel receptionist needs the most. (4) Based on the Front Office Standard Manual of Four Season Resort Bali at Jimbaran Bay, receptionist main responsibility are to handle check-in and check-out. This unit covers the most language functions needed to support hotel check-in and check-out. Based on that, five units were developed namely, Hotel Check-in, Hotel Check-in Without Reservation, Giving Recommendation, Hotel check-out, and Hotel Check-out with Problems in the development of hotel front office English listening materials.

There were two expert judge and a practitioner who judge the developed materials. From their judgment developed materials could be revised into learning materials that had good quality to be used to support the teaching and learning process in the classroom. This material consider as a good materials because it meets the principles of materials development proposed by Tomlinson (2003) and fill the criteria of a good listening text proposed by Wilson (2008). There were only 11 principles used as basic references of developing computer-assisted hotel front office English listening materials for students of hotel accommodation division of Mediterranean Hotel and Cruise Line Training Centre. Those are: (1) Materials should achieve impact (2) Material should help learners to feel at ease (3) Material should help learners to develop confidence (4) Material that taught should be relevant and useful (5) Material should require and facilitate learner self-investment (6) Material should expose the learners to language in authentic use (7) Material should provide learners with opportunities to use the target language (8) Material should take into account that the positive effect of instruction are usually delayed (9) Material should maximize learning potential by encouraging intellectual, aesthetic and emotional involvement which stimulates both right and left brain activities (10) Material should reflect the reality of language use (11) Material should help the readiness to learn.

The quality of English material perceived by expert judges and practitioner was good, shown by the coefficient 169.3 .

The result obtained used formula of scoring material design by Candiasa (2010:64) The researcher believed the final quality of the materials are more than good as revision were done based on vulnerable suggestions from the expert judges and the practitioner. 


\section{Discussion}

The announced of ASEAN Economic Community that enables free flow skilled labor open a wide opportunity for the worker to compete in ASEAN level. Tourism has been one of the key growth sectors in ASEAN and has proven strong among economic challenges globally. Competitive output from education and training provider are expected to be skillful in giving service as well as to have a good foreign language competency to conduct an effective communication.

Harun and Blue (2003) argued about a rapidly growing activity entailing cross-cultural communication between hosts and guest from different linguistics backgrounds which is international travel. It caused a growing worldwide need for frontline-staff (as hosts) in the tourism industry that are able to communicate effectively with guests. Therefore, having a good English proficiency considered as important.

Education and training provider should conduct an ESP training to have a graduates that meet the needs of the tourism industry. Harding (2007) stated that in ESP the purpose for learning the language is paramount and relates directly to what the learners needs to do in their vocation or job. Thornbury (2006) stated that ESP contrast with general English. The content and aim of the course are determined by the specific needs of the particular group of learners. The needs are normally identified by means of need analysis.

Polona (2012) conducted a study on preparing materials for ESP teaching. This study concerned on some aspects of ESP that was decisive for materials selection, as well as materials adaptation and/or writing. It involved needs analysis and syllabus design in addition to materials selection. All these tasks were equally demanding and contribute to the success of the ESP teaching/learning process. In relation to this study, Need analysis were done in the beginning of the study. The researcher did an observation and interview to obatain the need both of the students and the tourism industry in order to be a competent receptionist.

The materials were developed in an online learning platform to promote independent learning and because this type of learning offers many benefit. Dudeney and Hocky (2007) mentioned several some benefit of online learning such as, (1) Internet access either in private homes or at internet cafes is becoming increasingly available to learners. (2) Younger learners are growing up with technology, and it is a natural and integrated part of their lives. For these learners the use of technology is a way to bring the outside world into classroom. And some of these younger learners will in turn become teachers themselves. (3) English, as an international language, is being used in technologically mediated contexts. (4) Technology, especially the internet, presents us with new opportunities for authentic tasks and materials, as well as access to a wealth of ready-made ELT materials. (5) Learners increasingly expect language schools to integrate technology into teaching. (6) Technology offers new ways for practicing language and assessing performance. (7) Technology is becoming increasingly mobile. It can be used not only in the classroom, lecturer hall, computer room or self-access centre; it can always be used at home, on the way to school and in the internet cafes. (8) Using a range of ICT tools can give learners exposure to and practice in all of the main language skills - speaking, listening, writing and reading.

Eventhough, from the research it was also found that there were some challenge in the using of the online learning platform such as, connection problem, the feedback cannot be as precise as the teacher's given by the teacher but he developed of this English listening materials are expected to be able to motivate the students in improving their communication skills to be a competent receptionist as it is categorized as a good quality learning materials. This quality was obtained from the expert judges and practitioner.

\section{CONCLUSION}

Considering from the problem and the analysis that have discussed above, there were several conclusions based on the need analysis, the development of the English listening resource materials and the evaluation process they are:

1. Listening skills is essential for working in the tourism industry especially for hotel front office to be able to address guests' needs appropriately. 
2. The researcher did several steps to develop the materials. First, analyze documents such as curriculum, syllabus, textbook, teacher's diary, and teacher's action plan. Second, designing the blueprint of the materials. Third, collecting textbook that provides conversations which were needed to support the materials. Fourth, writing the script to be recorded. Fifth, recording the listening materials. Sixth, creating follow up exercises to enrich the materials. Seventh, uploading the recording and creating the materials to the learning platform.

3. There are five topics that were developed based on the interview with the practitioners. They stated that front office mostly handles check-in, check out and provides information to the guest. The topics are handling check-in, handling check in with no reservation, giving recommendation, handling check-out, and handling check-out with problems. phrases, practice responding to a certain situation and there is also a final speaking task to see the improvement of the students.

4. The computer-assisted hotel front office English listening materials were developed in Moodleclouds. It is a learning platform that enables the researcher to create fun and engaging online courses.

5. Materials Evaluation was done in order to know the quality of the developed materials that had been created through the Research and Development (R\&D) for Hotel Accommodation division. The materials were judged by experts and a practitioner. The result of the evaluation showed that the computer-assisted hotel front office English listening materials were appropriate for supporting students of Hotel Accommodation division. The developed resource materials had a good quality.

\section{CREDITS}

The writer also would like to thank both of her supervisors, Prof. DR. I Nym. Adi Jaya Putr, M.A. and Made Hery Santosa, M.Pd., PhD. that had spent much of their time to guide, suggest, correct and encourage during the process of writing this research.

\section{REFERENCES}

Bardi, J. A. 2003. Hotel Front Office Management. Canada: John Wiley \& Sons, Inc.

Bierema, L.L, and Merriam, S.B. 2014. Adult learning theory and practice. San Francisco: JoseyBass

Blue, G.M., Harun, M. Hospitality Lanauge as a Professional Skill. English Specific Purposes p 22 (2003) 73-79. www.elsevier.com/locate/esp

Candiasa, I M. (2010). Statistik Univariant dan Bivariant Disertai Aplikasi SPSS.Singaraja: Unit Penerbitan Universitas Pendidikan Ganesha.

Celce-Murcia. M. 2001. Teaching English as a second or foreign language. Third edition. USA: Heinle \& Heinle.

Dudeney, G. and Hockly, N.ityt

2007. How to Teaching English with Technology. England: Longman.

Harding, K.. 2007. English for Specific Purposes-Resource Books for Teachers. Oxford: Oxford University Press.

Hutchinson, T, and Walters, A. 1987. English for Specific Purposes: A Learning-centered approach. United Kingdom: Cambridge University Press.

McGriff, S. J. 2000. Instructional System. College of Education Penn State University.

Richard, J. C., and Schmidt, R. 2002. Longman Dictionary of Language Teacing and Applied Linguistics. London: Longman. 
Tomlinson, B.. 1998. Materials Development in Language Teaching. Cambridge: Cambridge University Press.

Tomlinson, B.. 2001. The Cambridge Guide to Teaching English to Speakers of Other Languages. Cambridge: Cambridge University Press.

Tomlinson, B.. 2003. Developing Materials for Language Teaching. London: Continuum.

Tomlinson, B.. 2012. Materials development for language learning and teaching. Cambridge: Cambridge University Press. 